\title{
D.H. V. CZECH REPUBLIC: ROMA EDUCATIONAL EQUALITY AND THE VULNERABILITY OF STRATEGIC LITIGATION
}

\section{FILIP SYS}

BPP UNIVERSITY, LONDON

\begin{abstract}
In 2007, the Grand Chamber of the European Court of Human Rights ruled that 18 Czech Roma primary school children had been unlawfully placed into special schools, designed for "mentally handicapped" children, and were subject to indirect racial discrimination. D.H. and Others $v$. the Czech Republic, a landmark piece of strategic litigation, hoped to catalyse tangible Czech educational reform; however, reports persist of Roma educational segregation. Firstly, this study briefly investigates why strategic litigation is an attractive, albeit obstacle-ridden, tool to effect societal reform. The study then conducts an in-depth impact analysis of D.H., focusing on Czech legal reactions and supranational developments and the post-judgment responses of the Czech Roma community. The study concludes that strategic litigation is a potent tool to effect social change but, regarding implementation and obstacles to its use and impact, remains vulnerable if not used in conjunction with extra-legal activism.
\end{abstract}

Keywords: strategic litigation; extra-legal activism; educational desegregation; Roma; European Court of Human Rights; Czechia

DOI: $10.14712 / 23363231.2020 .10$

This paper draws upon research conducted at the University of Nottingham for a final-year assessed undergraduate dissertation.

Filip Sys is a postgraduate student in Corporate Legal Practice LL.M. at BPP University, London. Address correspondence to Filip Sys, BPP University, 68-70 Red Lion St., Holborn, London, WC1R 4NY, United Kingdom. E-mail: filip.sys1@gmail.com. 


\section{Introduction}

Through the lens of D.H. and Others $v$. the Czech Republic ${ }^{1}$ (hereafter D.H.) and Roma educational desegregation efforts in Czechia, this study will assess the use and impact of strategic litigation in effecting social change, specifically reviewing reforms to domestic and supranational legal landscapes and the responses of the Czech Roma community.

Considering the historic plight of Roma school children in Czechia, education is a key to equality and an important counter to socially pervasive stereotypes. In 1999, the Czech Constitutional Court witnessed the beginnings of a lengthy legal challenge which culminated in the first supranational case addressing the educational segregation of Roma children in national education systems. ${ }^{2}$ Finally reaching conclusion at the Grand Chamber of the European Court of Human Rights (ECtHR) in 2007, the case of D.H., for the first time in European Convention jurisprudence, found an entire national policy to have a "disproportionally prejudicial effect". ${ }^{3}$ Not only did the judgment compel Czechia to modify its entire system of primary education ${ }^{4}$ but it was, and still is, a proactive message of educational desegregation across Europe where similar abuses against Roma children have been reported.

$D . H$. is a prime example of what is known as strategic litigation: legal action designed to not only vindicate the rights of applicants, but to importantly contribute to a wider package of activism in an attempt to redress widespread abuses and create social impact. Under the rights afforded by the European Convention on Human Rights (ECHR), ${ }^{5}$ the Grand Chamber found that 18 Czech Roma

1 D.H. and Others v. the Czech Republic (hereafter D.H.), App. No. 57325/00, European Court of Human Rights (hereafter ECtHR) Grand Chamber, November 13, 2007, http://hudoc.echr.coe .int/fre? $\mathrm{i}=001-83256$.

2 Adriana Zimová et al., Strategic Litigation Impacts: Roma School Desegregation (New York: Open Society Foundations, 2016), 22, https://www.justiceinitiative.org/uploads/5731f49e-92ba-4adf -976f-156dcaaffe7c/strategic-litigation-impacts-roma-school-desegration-20160407.pdf.

3 D.H., November 13, 2007, para. 209.

4 Hubert Smekal and Katarína Šipulová, “D.H. v. Czech Republic Six Years Later: On the Power of an International Human Rights Court to Push Through Systemic Change”, Netherlands Quarterly of Human Rights 32, No. 3 (April 2017), 289-290, doi: 10.1177/016934411403200305.

5 Convention for the Protection of Human Rights and Fundamental Freedoms (as amended by protocols No. 11 and 14, supplemented by protocols No. 1, 4, 6, 7, 12 and 16), homepage of the European Court of Human Rights - Council of Europe, https://www.echr.coe.int/Documents /Convention_Eng.pdf; transposed into Czech law by Sdělení č. 209/1992 Sb. Sdělení federálního ministerstva zahraničních věcí o sjednání Úmluvy o ochraně lidských práv a základních svobod a Protokolů na tuto Úmluvu navazujících. 
applicants, former primary school children or attendees at the time, were denied the right to education (Art. 2, Protocol 1) and were subject to discrimination on account of their racial identity (Art. 14) when placed into special schools designed for "mentally handicapped" children. However, the wider effect of $D$.H. was to vicariously represent the denied rights of a historically marginalised community, systemically reform national education policy and attempt to break the generational abuse of "[excluding] Roma children from mainstream society at the very beginning of their lives". ${ }^{6}$

Strategic litigation is an appealing prospect; however, from the outset, obstacles such as hostile socio-political environments, selecting the most effective case or overall strategy and the risk of impotent judicial remedies can create a perilous litigation journey. Furthermore, a favourable authoritative judgment like $D . H$. can only do so much in implementing effective reforms for the intended beneficiaries. As a consequence, extra-legal activism, defined in this study as measures which are beyond litigation and post-judgment legislative reforms, is an essential partner to strategic litigation before, during and after legal challenges. Whether collecting ethnically disaggregated data of Roma children in special education, creating victim empowerment projects, raising public awareness or giving agency to Roma communities, strategies to effect reform must not lose sight of the vital role of extra-legal activism. This study is not a forensic investigation into the changing legal position of Czech education policy post-D.H., a critique of ECtHR discrimination jurisprudence, nor a discussion of how to give Roma agency when defending their educational rights. Rather, it intends to both describe the vulnerability of solely relying on strategic litigation (a legal response to abuses), but also argue for the coexistence of legal and extra-legal forms of redress in order to effectively challenge the status quo.

The study comprises an in-depth literature review and legal analyses of D.H., subsequent Roma educational desegregation litigation and relevant Czech legislation. When analysing the academic discussion concerning explicit calls for strategic litigation or other legal forms of redress, the subject matter is limited. This is especially true when regarding Roma educational desegregation. Numerous academics cited in this study, including Smekal and Šipulová ${ }^{7}$ and Kosař and

6 Álvaro Gil-Robles, Final Report by Mr Álvaro Gil-Robles, Commissioner for Human Rights: On the Human Rights Situation of Roma, Sinti and Travellers in Europe (Strasbourg: Office of the Commissioner for Human Rights, 2006), 20.

7 Smekal and Šipulová, "D.H. v. Czech Republic Six Years Later”. 
Petrov $^{8}$, discuss D.H. regarding the effectiveness of international human rights courts or challenges to state compliance. This is a common discussion, but what is often missing in research is an analysis of how to address the evident vulnerability of strategically litigated cases.

Within post-judgment monitoring reports and submissions from major actors in the field of Roma educational desegregation, including the Open Society Justice Initiative (OSJI), the OSCE and the European Roma Rights Centre (ERRC), the need for extra-legal methods to strengthen legalistic responses to abuses is presented through advocating for a package of activism to effect systemic change. Although not always explicitly calling for the coexistence of legal and extra-legal forms of activism, various monitoring reports and submissions were used in this study in order to develop the argument. Quantitative data from international organisations, NGOs and government statistics were gathered to present strong data-based arguments as well as conflicts between government ministries and national and international monitors.

Enhancing the literature review and case analyses, primary research was conducted. A formal phone-interview with James A. Goldston, Chief Executive of the OSJI and one of the lead counsels to the D.H. applicants, was important in understanding not only how a key actor viewed challenges to the lasting impact of D.H., but also the positive legal and social developments since the judgment. ${ }^{9}$ In addition, I made a field visit to a Člověk v tísni (People in Need) youth centre in Kladno, Central Bohemia. This visit gave the study first-hand insight into how an emancipatory judgment like $D . H$. can be weaponised locally to effect change. ${ }^{10}$

\section{The Attractive and Obstacle-Ridden Pursuit of Strategic Litigation}

Using D.H. and the wider issue of Roma educational desegregation, this part of the study will briefly explore why strategic litigation is an attractive, albeit obstacle-ridden, tool to effect societal reform from both an emotional and practical perspective. Even assessing the appeal of strategic litigation, it is evident

${ }^{8}$ David Kosař and Jan Petrov, "Detriments of Compliance, Difficulties among 'Good Compliance': Implementation of International Human Rights Rulings in the Czech Republic", The European Journal of International Law 29, No. 2 (May 2018), doi: 10.1093/ejil/chy028.

9 Filip Sys, "The Legacy of D.H. v. Czech Republic: A Discussion with James Goldston" (hereafter Interview with James Goldston), Fil Sys Blog, January 22, 2019, https://filsysblog.wordpress .com/2019/01/22/the-legacy-of-d-h-v-czech-republic-a-discussion-with-james-goldston/.

${ }^{10}$ Filip Sys, "The Hostel on the Hill”, Fil Sys Blog, May 30, 2018, https://filsysblog.wordpress .com/2018/05/30/the-hostel-on-the-hill/. 
that legal strategies alone are vulnerable to various obstacles and, consequently, extra-legal activism must play a pivotal role in implementation efforts.

Transforming reports of abuses into legal arguments has practical appeal to litigators, activists and victims because it is an opportunity to "produce legally binding enforcement" of states' obligations. ${ }^{11}$ In D.H., the Grand Chamber, short of instructing the Czech government, urged the use of special schools as an option of last resort and recommended teachers be given training and resources to aid struggling pupils in mainstream primary schools. ${ }^{12}$ It is questionable, but for D.H., whether the Czech government would have independently sought to reform the national education system to redress Roma educational inequality. The case of Horváth and Kiss, ${ }^{13}$ concerning two young Roma men in Hungary who had previously attended sub-standard special schools, further illustrates the point. Taking unprecedented steps, the Second Section of the ECtHR imposed positive obligations to provide educational support to Roma in mainstream primary schools ${ }^{14}$ and negative obligations to avoid indirect discrimination during psychological testing and practices, ${ }^{15}$ occurring when neutrally worded legislation or policies have a disproportionate effect on members of a group sharing protected characteristics. ${ }^{16}$ The practical appeal, therefore, lies in the fact that strategic litigation can compel respondent states to take reforming action when no such activity was previously contemplated.

Despite the practical appeal of strategic litigation, one cannot be naïve to the challenges of implementation. For example, regarding D.H. in the Czech context, a historically hostile socio-political environment creates an obstacle to the influence that an authoritative judgment can organically foster. Public opinion before and after D.H. paints a picture of hostility towards the Roma community.

11 Open Society Justice Initiative (hereafter OSJI), Strategic Litigation Impacts: Insights from Global Experience (New York: Open Society Foundations, 2018), 32-33, https://www.justi ceinitiative.org/uploads/fd7809e2-bd2b-4f5b-964f-522c7c70e747/strategic-litigation-impacts -insights-20181023.pdf.

12 Arlan Fuller, "Case Studies: Community Development - Combatting Segregation in Czech Republic", in Strategies and Tactics to Combat Segregation of Roma Children in Schools: Case Studies from Romania, Croatia, Hungary, Czech Republic, Bulgaria and Greece, ed. Margareta Matache et al. (Boston: FXB Center for Health and Human Rights Harvard University, 2015), 77, https://cdn1 .sph.harvard.edu/wp-content/uploads/sites/2464/2020/01/Roma-Segregation-full-final.pdf.

${ }^{13}$ Horváth and Kiss v. Hungary, App. No. 11146/11, ECtHR Second Section, January 29, 2013.

14 Ibid, para. 104.

15 Ibid, para. 105 and 106.

${ }^{16}$ Council of Europe and European Union Agency for Fundamental Rights, Handbook on European Non-Discrimination Law (Luxembourg: Publications Office of the European Union, 2018), 53, https://www.echr.coe.int/Documents/Handbook_non_discri_law_ENG.pdf. 
In 1992, a Respekt magazine poll found that 45 percent of Czechoslovaks wanted all Roma to leave the country ${ }^{17}$ and, in 2018, the Public Opinion Research Centre CVVM under the Czech Academy of Sciences recorded that 73 percent of Czechs found Roma "quite or very unpleasant". ${ }^{18}$ Furthermore, research into attitudes towards Roma children show common stereotypes that Roma pupils are "unruly" 19 and a still present ethnocentric opinion that Roma are "intellectually inferior". ${ }^{20}$ Such ingrained attitudes towards the Roma community are conducive to a mostly non-violent hostile environment ${ }^{21}$ which creeps into national policies and is often subject to denial when allegations of abuse surface. ${ }^{22}$ Therefore, simply relying on strategic litigation to independently reform hostile environments is futile and requires extra-legal activism to confront underlying discriminatory attitudes and inequalities. For example, $D . H$. vindicated children's rights to equal education, but it did not take into account the remaining residential inequality faced by Roma communities which creates racially homogenous school districts. Perhaps recognising this, in 2018, the Czech Ombudsman issued recommendations for the facilitation of school buses for Roma pupils to and from mixed mainstream primary schools. ${ }^{23}$ Although short-sighted, as "white flight” has consistently been recorded from mixed primary schools where Roma

17 Petr Janyška, "Menšina a většina" [Minority and Majority], Respekt, January 6, 1992, https://www .respekt.cz/tydenik/1992/1/mensina-a-vetsina?issueId=112.

18 Milan Tuček, Vztah české veřejnosti k národnostním skupinám žijícím v ČR - březen 2018 [Attitude of the Czech General Public towards National Minority Groups Living in Czechia - March 2018] (Praha: Centrum pro výzkum veřejného mínění, 2018), https://cvvm.soc.cas.cz/cz/44-tiskove -zpravy/ostatni/vztahy-a-zivotni-postoje/4588-vztah-ceske-verejnosti-k-narodnostnim-skupinam -zijicim-v-cr-brezen-2018?idU=1.

19 Gregor Maučec, "Identifying and Changing Stereotypes Between Roma and Non-Roma: From Theory to Practice", Innovative Issues and Approaches in Social Sciences 6, No. 3 (September 2013): $184-185$.

20 UNICEF, The Right of Roma Children to Education (Geneva: UNICEF CEECIS, 2011), 21, https://www.unicef.org/eca/media/1566/file/Roma\%20education\%20postition\%20paper.pdf, 2019.

21 Pavel Bílek et al., Zpráva o stavu lidských práv v České republice 1996 [Report on the State of Human Rights in the Czech Republic in 1996], April 1997, 35-38, http:/ /www.helcom.cz/cs/zpravao-stavu-lidskych-prav-v-cr-za-rok-1996/.

22 Rick Fawn, “Czech Attitudes toward the Roma: 'Expecting More of Havel's Country?’”, Europe-Asia Studies 53, No. 8 (December 2001): 1195, doi: 10.1080/09668130120093192.

23 "Ombudsmanka doporučila deset opatření k lepší integraci Romů do běžných škol a mezi ostatní děti” [Ombudsman Recommends Ten Measures to Better Integrate Roma into Mainstream Schools with Other Children], Romea.cz, December 12, 2018, http://www.romea.cz/cz /zpravodajstvi/domaci/ombudsmanka-doporucila-deset-opatreni-k-lepsi-integraci-romu-do -beznych-skol-a-mezi-ostatni-deti. 
children start attending, ${ }^{24}$ extra-legal measures like these over a sustained period of time and coupled with other activism have a chance to translate courtroom success into on-the-ground reforms.

Although tangible reforms are far from guaranteed, cases of strategic importance have a raw emotional aspect which can create "emancipation stories". ${ }^{25} \mathrm{On}$ hearing the Grand Chamber's judgment, one Roma parent of the D.H. applicants poignantly stated: "someone [...] finally believed us... [we were] able to make it to Strasbourg and tell the truth." ${ }^{6}$ Successful test cases like D.H. have the ability to provide an emotional cornerstone on which victims, NGOs and other stakeholders can rely and build. Demonstrating the solid foundation that a successful piece of strategic litigation can offer, a recent Ostrava District Court case in 2017, which heard claims concerning the blocking of two Roma boys' applications to a local elementary school, found a violation. ${ }^{27}$ The precedent set by the Grand Chamber in D.H., ten years previously, made clear to the District Court that admission policies which are shown to have a disproportionately negative effect on Roma can be deemed to be racially discriminative.

Given the hostility of some environments and the emotional weight of strategic litigation, it is vital to select the right strategy to redress widespread discriminatory practices. Whether a selected case to litigate, an alternative advocacy option (like amicus curiae) or deciding on exclusively extra-legal methods, what needs to be avoided is the alienation of victims and their perception that justice is "dependent" on the efforts of "strangers". ${ }^{28}$ Especially when considering a legal reaction to abuses, if one can include victimised communities in the process, for example through legal teams updating community representatives or hosting presentations on case developments, a more lasting and inclusive solution may be found. Again, the partnership between strategic litigation and extra-legal activism is vital.

Part of the reason why considering the strategy in strategic litigation is important is because successful test cases are often part of lengthy, sequential

${ }^{24}$ Antonia Eliason, "With No Deliberate Speed: Understanding and Maximising Litigation”, Duke Journal of Comparative and International Law 27, No. 2 (Winter 2017): 205, https://scholarship .law.duke.edu/djcil/vol27/iss2/2.

25 Adam Weiss, "What is Strategic Litigation?", European Roma Rights Centre (hereafter ERRC), June 1, 2015, http://www.errc.org/news/what-is-strategic-litigation.

26 Zimová et al., Strategic Litigation Impacts: Roma School Desegregation, 69.

27 "JusticeServed-RomaniBoysDeniedEnrolmentin SchoolWin Casein Czech Republic",ERRC,March 6, 2017, http://www.errc.org/press-releases/justice-served--romani-boys-denied-enrolment -in-school-win-case-in-czech-republic.

28 OSJI, Strategic Litigation Impacts: Insights from Global Experience, 37. 
plans to effect reform. Considering European Roma educational desegregation efforts, there is certainly no discernible "champagne moment" 29 and it is still an incremental process to emancipation. Thought to have started in Hungary when Roma students complained of segregated canteens and graduation ceremonies, ${ }^{30}$ it was not until $D . H$. that strategic litigation was employed more as a method to advance Roma educational rights. ${ }^{31}$ Since D.H., the ECtHR has denounced the physical segregation of Roma children in mixed schools in Sampanis, ${ }^{32}$ refused to accept language proficiency as grounds to segregate Roma children in Oršus $\breve{s}^{33}$ and added clarity that neutral educational practices cannot be indirectly discriminative in Horváth and Kiss. Thus, D.H. may be remembered as one landmark judgment, but the construction of an "emancipation story" may require many chapters to fully shift the status quo in favour of Roma educational equality.

Even in this study's brief discussion on the attractiveness and challenges of strategic litigation, extra-legal activism has been shown to be essential in keeping the spotlight on respondent states. As a series of Greek Roma educational desegregation cases at the ECtHR demonstrate, sustained extra-legal pressure is vital when judgments do not provide an adequate deterrent or have an unhelpful tone which fails to express urgency. Similarly to D.H., in 2008, judges in Sampanis allowed the Greek government to choose the means of redress after unanimously finding Greece in violation when Roma pupils were segregated into off-site annexes in mainstream primary schools - crucially not requiring the offending school board to cease segregationist policies. ${ }^{34}$ Although the Committee of Ministers of the Council of Europe deemed the post-judgment measures of the Greek government satisfactory, ${ }^{35}$ the freedom afforded by the ECtHR was shown to be ineffective, when, in another Greek case in 2012, the said reforms had merely helped to create Roma-only primary schools (Sampani). ${ }^{36}$ Similar violations

${ }^{29}$ Helen Duffy, Strategic Human Rights Litigation: Understanding and Maximising Litigation (Oxford: Hart Publishing, 2018), 37-38.

30 "Roma Sue School in Northeastern Hungary: The Submission Against the Principal of the Ferenc Pethe Primary School, Tiszavasvári, Hungary", ERRC, May 14, 1998, http://www.errc.org /roma-rights-journal/roma-sue-school-in-northeastern-hungary-the-submission-against-the -principalof-the-ferenc-pethe-primary-school-tiszavasvari-hungary.

31 Zimová et al., Strategic Litigation Impacts: Roma School Desegregation, 21-22.

32 Sampanis and Others v. Greece, App. No. 32526/05, ECtHR First Section, June 5, 2008.

33 Oršuš and Others v. Croatia, App. No. 15766/03, ECtHR Grand Chamber, March 16, 2010.

34 Jack Greenberg, "Report on Roma Education Today: From Slavery to Segregation and Beyond", Colombia Law Review 110, No. 4 (May 2010): 943-945.

35 James A. Goldston, "The Unfulfilled Promise of Educational Opportunity" in Realising Roma Rights, ed. Jacqueline Bhabha et al. (Philadelphia: University of Pennsylvania Press, 2017), 173.

36 Sampani and Others v. Greece, App. No. 59608/09, ECtHR First Section, December 11, 2012. 
were found in Lavida in 2013. ${ }^{37}$ The lack of urgency by the court in some Roma educational desegregation litigation is therefore exactly why extra-legal activism is required - it ensures the promises made in judgments are not diluted or ignored.

\section{The Multi-Dimensional Impact of D.H. v. Czech Republic}

Analysing D.H. and educational desegregation efforts in Czechia, this part will conduct a specific impact analysis on changes to domestic legal and supranational landscapes and the Roma response post-judgment. It is here where one can see, by means of a focused case study, the necessity of strategic litigation and extra-legal activism having a close relationship in order to achieve maximum social impact.

When measuring impact, this study reviewed reports from public interest organisations and NGOs that regularly monitor the results of their legal challenges. For example, the OSJI appraised its Roma desegregation litigation in 2016 by reviewing the post-judgment policies and practices of the respondent state, any legal and jurisprudential developments and the effect on "peoples' lives". ${ }^{8}$ The OSJI later adopted an explicitly multi-dimensional approach, using a "material, instrumental and non-material" model. ${ }^{39}$ Also considering Duffy's call for "high definition" and "wide-angled" impact perspectives ${ }^{40}$ this study focused on jurisprudential and socio-legal issues from wide topic areas, for example the treatment of data in supranational jurisprudence post- $D . H$., to provide a useful picture of impact.

\section{Changing Legal and Jurisprudential Landscapes}

Regarding impact, it is perhaps the legal and jurisprudential developments following $D$.H. which can be seen as having a timeless effect. Whether reviewing Czech domestic reforms or the elevation of data in European Convention jurisprudence, there must exist a close partnership between legal forms of redress, like strategic litigation, and extra-legal activism. This is vital in preventing courtroom successes being squandered in practice.

${ }^{37}$ Lavida and Others v. Greece, App. No. 7973/10, ECtHR First Section, May 30, 2013.

38 Zimová et al., Strategic Litigation Impacts: Roma School Desegregation, 55.

39 OSJI, Strategic Litigation Impacts: Insights from Global Experience, 42-43.

40 Duffy, Strategic Human Rights Litigation, 37-41. 
Prior to D.H., it was Czechoslovak, later Czech, legislation and educational practices which enabled the effective segregation of Roma children in the national education system. Under the provisions of the Schools Act 1984 (1984 Act), children could be placed into special primary schools (zvláštníškoly) which were designed for those deemed to have a mild mental disability, including those "difficult to educate", ${ }^{41}$ a common stereotype that Roma children persistently face. Furthermore, a 1997 Ministerial Decree gave head teachers the power to decide on the appropriateness of a child's special school placement on account of an individual psychological report and parental consent. ${ }^{42}$ Perhaps realising that inconsistent psychological testing was being used and there existed a shaky concept of parental consent, an amendment was passed in $2000^{43}$ which allowed for "special school graduates" to attend mainstream secondary schools on passing an entrance exam. ${ }^{44}$ Such a measure neglected the fact that the woefully abridged special school curriculums left children unprepared for such an entrance exam, nor did it facilitate the pursuit of any other forms of further education..$^{45}$ Roma children were trapped in a cycle of educational poverty.

By the time D.H. was heard at the Grand Chamber, the Czech government had arguably already felt the impact of judicial scrutiny. In 2004, Czechia had repealed the 1984 Act and had introduced a new Schools Act (2004 Act) which aimed to integrate special and mainstream primary schools. ${ }^{46}$ Due to fierce anti- $D . H$. lobbying, however, crucial changes were reversed and instead special schools were simply renamed "practical schools" (praktické školy). ${ }^{47}$

${ }^{41}$ Zákon č. 29/1984 Sb. Zákon o soustavě základních a středních škol (školský zákon) [On the System of Primary and Secondary Schools (Schools Act)], \$ 29 (1), https://www.zakonyprolidi.cz /cs/1984-29.

42 Vyhláška č. 127/1997 Sb. Vyhláška Ministerstva školství, mládeže a tělovýchovy o speciálních školách a speciálních mateřských školách [Decree of the Ministry of Education, Youth and Sports on Special Schools and Special Kindergartens], $\mathbb{~ 7 , ~ h t t p s : / / w w w . z a k o n y p r o l i d i . c z / c s / 1 9 9 7 - 1 2 7 . ~}$

43 Zákon č. 19/2000 Sb. Zákon, kterým se mění Zákon č. 29/1984 Sb., o soustavě základních škol, středních škol a vyšších odborných škol (školský zákon), ve znění pozdějších předpisů [Amendment to Schools Act 1984], https://www.zakonyprolidi.cz/cs/2000-19.

${ }^{44}$ Barbora Bukovská and Pavla Boučková, "Minority Protection in the Czech Republic", in Monitoring the EU Accession Process: Minority Protection, ed. Open Society Institute (New York: Central European University Press, 2002), 138.

45 Zimová et al., Strategic Litigation Impacts: Roma School Desegregation, 37.

46 Zákon č. 561/2004 Sb. Zákon o předškolním, základním, středním, vyšším odborném a jiném vzdělávání (školský zákon) [On Pre-School, Primary, Secondary, Higher Vocational and other Education (Schools Act)], https://www.zakonyprolidi.cz/cs/2004-561.

47 Laura Cashman, "No Label No Progress: Institutional Racism and the Persistent Segregation of Romani Students in the Czech Republic”, Race Ethnicity and Education 20, No. 5 (2017): 597-598, doi: 10.1080/13613324.2016.1191698. 
Problematically, the 2004 Act, in what is quite ethnocentric language, described children from a "low socio-cultural status" as being in need of special educational attention. ${ }^{48}$ Further worsening the situation, Ministerial Decrees in 2005 allowed for pupils without a declaration of mild mental disability to be placed into practical schools merely on the basis of parental consent. ${ }^{49}$ As Smekal and Šipulová reported, these developments resulted in 60 percent of all recorded Roma pupils in 2009 attending practical (formerly special) schools purely on the basis of parental consent, ${ }^{50}$ showing a void in informed consent.

Since D.H., the Czech legal response has been characterised by inaction, opposition and fluctuating attitudes leading to "cosmetic changes" 51 and little progress. Initially the response to the judgment was promising with Education Minister and D.H. advocate, Ondřej Liška, keen to collaborate with civil society and academics to create an implementation framework to desegregate national schooling. ${ }^{52}$ This culminated in a draft Action Plan for the Educational Inclusion of Roma in 2007.53 Although this particular Action Plan was rejected by the Czech Parliament's Chamber of Deputies in the same year, followed by the untimely departure of Liška in 2009 due to a vote of no-confidence in the government in which he served, the initial principle of extra-legal collaboration remained. For example, when a new National Action Plan for Inclusive Education (Národní akční plán inkluzivního vzdělávání) was finally created in 2010, a working group was established to implement it and, within that group, civil society played a key role. ${ }^{54}$ These positive steps demonstrated that, in order to implement a judgment effectively and ensure that reforms tangibly reach victimised communities, it is essential to work with extra-legal actors who have a more in-depth knowledge of the issues facing Roma.

${ }^{48}$ Laura Fónadová, Tomáš Katrňák and Natalie Simonová, “The Czech Republic: From Ethnic Discrimination to Social Inclusion in the Education System" in The Palgrave Handbook of Race and Ethnic Inequalities in Education, ed. Peter A. J. Stevens et al., 2nd ed. (Cham: Springer, 2019), 390-391.

49 Office for Democratic Institutions and Human Rights (hereafter ODIHR), Equal Access to Quality Education for Roma Children - Field Assessment to the Czech Republic (Warsaw: OSCE, 2012), 24-26, https://www.osce.org/odihr/96661.

50 Smekal and Šipulová, “D.H. v. Czech Republic Six Years Later”, 305.

51 Ibid.

52 Gwendolyn Albert, "Education policies in the Czech Republic", in Ten Years Later: A History of Roma School Desegregation in Central and Eastern Europe, ed. Iulius Rostas (Budapest: Central European University Press, 2012), 180-182.

53 Fuller, "Case Studies: Community Development", 77.

54 Smekal and Šipulová, “D.H. v. Czech Republic Six Years Later”, 305. 
This attitude did not last. By the time Josef Dobeš became Education Minister in 2010, significant pressure from some special education groups and other anti-D.H. actors had helped politicise the judgment and the inclusion of Roma pupils into mainstream primary education. After a new Czech Penal Code was passed in early 2010, explicitly criminalising segregation, the government approved the National Action Plan and allowed a multi-stakeholder working-group to implement measures. ${ }^{55}$ However, after a negligible amount of working-group meetings and the termination of the operations of the ministerial department charged with implementing inclusive education, over half of the National Action Plan experts resigned over a lack of express governmental commitment. ${ }^{56}$ Furthermore, when the Czech government constructed the Strategy for Combatting Social Exclusion (Strategie boje proti sociálnímu vyloučení na obdobi 2011-2015) in 2011, aimed at completely abolishing schools for "mildly mentally handicapped" children and reforming the system of financial incentives in the education system, the Ministry sided with the concerns of the anti-D.H. lobby rather than pledging support for the Grand Chamber's ruling in 2007.57 Seeming to change attitudes again in 2012, the Ministry created another National Action Plan to desegregate schooling and has since communicated more frequently with the Committee of Ministers (Council of Europe). ${ }^{58}$ Regardless of the attitude of the Ministry, the fact remains that the then Czech Ombudsman, NGOs and other pro-D.H. actors did not "[possess] sufficient formal powers and the political capacity to push through systemic change against the existing opposition". 59

Despite the inaction and regression of the Czech government, national and international NGOs, like the OSJI, Amnesty International, the Together to School coalition (Společně do školy) and others, have been compiling reports on the progress of the Czech government in implementing D.H. since the 2007 judgment, consistently raising concerns. ${ }^{60}$ Such persistence from extra-legal actors contributed to the EU Commission launching infringement proceedings against Czechia in 2014, specifically citing D.H. and a joint NGO report when calling into question Czechia's compliance with the Racial Equality Directive. ${ }^{61}$ Currently,

55 Albert, "Education policies in the Czech Republic", 191-192.

56 Smekal and Šipulová, "D.H. v. Czech Republic Six Years Later”, 306.

57 Fuller, "Case Studies: Community Development", 82.

58 Kosař and Petrov, "Detriments of Compliance, Difficulties among 'Good Compliance”, 412-413.

59 Ibid.

${ }^{60}$ ODIHR, Equal Access to Quality Education for Roma Children, 27.

${ }^{61}$ Zimová et al., Strategic Litigation Impacts: Roma School Desegregation, 61; Council Directive 2000/42/EC of 29 June 2000 Implementing the Principle of Equal Treatment between Persons 
the EU Commission is still in dialogue with Czechia but, it is hoped that "the [...] action prompts swifter implementation of D.H. than we have seen to date". ${ }^{62}$ A causal link exists between extra-legal pressure, the Commission's infringement proceedings and recent legislative reforms to the Czech education system. Policies for inclusive education faced significant opposition from parts of the media and some organs of government but, nonetheless, amendments in 2015 to the 2004 Act re-directed resources to provide support for special educational needs (SEN) students at mainstream primary schools rather than at segregated practical schools. ${ }^{63}$ An enforceable right to educational support for children in mainstream primary schools was also introduced into law. ${ }^{64}$ Furthermore, Ministerial Decrees in 2016 reformed financial aid to mainstream primary schools by providing different levels of support in an attempt to fund "joint education". ${ }^{65}$ The Grand Chamber's judgment in D.H. was a legal response to systemic abuses but, rather than rely on the judgment itself to create the desired outcome, extra-legal actors maintained pressure and arguably catalysed an escalation in scrutiny and some recent reforms.

Regarding broader supranational impacts, $D . H$. was a jurisprudential landmark in a number of areas. It was particularly the recognition of reliable data to prove indirect discrimination which impressed on national governments that extra-legal measures (like collecting ethnically disaggregated data) are vital in implementing a judgment. Additionally, elevating the role of statistics to prove disproportionate impacts on ethnic minorities has acted to vindicate the watchdog role of NGOs.

In the early 2000s, scholars widely acknowledged that the equality jurisprudence of the ECtHR was rather underwhelming due, in part, to the court's

Irrespective of Racial or Ethnic Origin (EU), https://eur-lex.europa.eu/legal-content/en/TXT / ?uri=CELEX\%3A32000L0043.

${ }^{62}$ Interview with James Goldston, January 22, 2019.

${ }^{63}$ Zákon č. 82/2015 Sb. Zákon, kterým se mění zákon č. 561/2004 Sb., o předškolním, základním, středním, vyšším odborném a jiném vzdělávání (školský zákon), ve znění pozdějších předpisů, a některé další zákony [Amendment to 2004 Act], https://www.zakonyprolidi.cz/cs/2015-82.

${ }^{64}$ Isabelle Chopin, Catharina Germaine, and Judit Tanczos, Roma and the Enforcement of Anti-Discrimination Law (Luxembourg: Publications Office of the European Union, 2017), 14, https:// op.europa.eu/en/publication-detail/-/publication/cd62f9fe-92ae-11e7-b92d-01aa75ed71a1 /language-en.

${ }^{65}$ Vyhláška č. 27/2016 Sb. Vyhláška o vzdělávání žákủ se speciálními vzdělávacími potřebami a žáků nadaných [Decree on the Education of Pupils with Special Educational Needs and Gifted Pupils], https://www.zakonyprolidi.cz/cs/2016-27. 
strict reading of discrimination based on intent (direct discrimination). ${ }^{66}$ Prior to D.H., there had been increasing calls, especially from litigators in a series of Bulgarian Roma murder cases, for the ECtHR to adopt the concept of indirect discrimination. In Velikova ${ }^{67}$ and Anguelova ${ }^{68}$, counsels argued that inadequate investigations, and the fact that racism was not considered as a motive for police officers killing Roma, was a breach of Art. 2 (right to life) which should be read in conjunction with Art. 14 (prohibition on discrimination). Counsels hoped that, by providing reliable statistical evidence demonstrating a prevailing discriminatory attitude in the Bulgarian police and public at large, the ECtHR would shift the burden of proof to Bulgaria to provide a non-discriminatory reason why racist motives were not considered. In Velikova, the Bulgarian government admitted to "popular prejudice against Roma" 69 and, in Anguelova, details revealed that police officers were "unable to refrain from referring to [the victim] as " the Gypsy'" ${ }^{70}$ Velikova and Anguelova failed to persuade the court to shift the the burden of proof; however, the First Section in Nachova, due to the Bulgarian authorities not investigating racial motives in two additional Roma murders, allowed the burden to shift to Bulgaria. ${ }^{71}$ Although the First Section's judgment in Nachova was overturned at the Grand Chamber, ${ }^{72}$ it signalled the ECtHR could be swayed to change its strict application of discrimination.

The D.H. judgment was significant because it was the first time the concept of indirect discrimination was applied in ECtHR jurisprudence. Throughout the D.H. litigations, the Bulgarian Roma murder cases were referenced, as was the EU Racial Equality Directive (RED) ${ }^{73}$ which, at the time, was the only instrument in Europe which recognised indirect discrimination. In D.H., the Second Section heard that the RED allowed a prima facie case of discrimination to be established when an "apparently neutral provision or practice" (like the 1984

${ }^{66}$ Andrea Coomber, "Strategically Litigating Equality - Reflections on a Changing Jurisprudence", European Anti-Discrimination Law Review 15, No. 11 (November 2012): 10-12, https://www .migpolgroup.com/_old/portfolio/european-anti-discrimination-law-review-issue-15/.

67 Velikova v. Bulgaria, App. No. 41488/98, ECtHR Fourth Section, May 28, 2000.

68 Anguelova v. Bulgaria, App. No. 38361/97, ECtHR First Section, June 13, 2002.

69 Velikova, 2000, para. 92.

70 Anguelova, 2002, para. 164.

${ }^{71}$ Nachova and Others v. Bulgaria, App. No. 43577/98 and 43579/98, ECtHR First Section, February 26, 2004.

72 Nachova and Others v. Bulgaria App. Nos. 43577/98 and 43579/98, ECtHR Grand Chamber, July 6, 2005.

${ }^{73}$ Council Directive 2000/42/EC of 29 June 2000 Implementing the Principle of Equal Treatment between Persons Irrespective of Racial or Ethnic Origin (EU), https://eur-lex.europa.eu /legal-content/en/TXT/?uri=CELEX\%3A32000L0043. 
Act) disproportionately disadvantaged "persons of a racial or ethnic origin" (like Roma $)^{74}$. Although the Second Section did not "rule out" the use of statistics to prove discriminatory practices, it stayed true to its strict application of discrimination by intent and warned against relying on such data. ${ }^{75}$ The Grand Chamber reversed the Second Section's judgment and not only used RED to define indirect discrimination, but shifted the burden to Czechia to provide a non-discriminatory justification for the disproportionate numbers of Roma children in special education. ${ }^{76}$ The Czech government was unable to provide such a justification.

The displacement of intent and the elevation of statistical evidence was therefore "a revolutionary breakthrough within the framework [...] of the ECtHR",77 with the cases of Sampanis, Oršuš, Sampani, Horváth and Kiss and Lavida also all presenting statistical evidence to demonstrate a breach of Art. 14 alongside Art. 2 of Protocol 1 (right to education). The positive treatment of statistics by the Grand Chamber, as Klípa suggests, signalled to the Czech government that extra-legal measures in the form of ethnic data collection were essential, not only in monitoring the placement of Roma into special education, but to assess the impact of any reforms post-D.H. ${ }^{78}$ It was reported by NGOs, shortly after the Grand Chamber's judgment, that government ministers regarded the collection of ethnically disaggregated data as a matter of urgency to prevent another D.H.-style case. ${ }^{79}$ Essentially, the Czech government had been put on notice to actively seek out legislation and practices which had an indirect discriminatory effect on Roma.

The Czech government's use of ethnic data collection did not start well. At first, a voluntary survey for head teachers was circulated throughout Czechia and, unsurprisingly, it resulted in unhelpful samples being taken. ${ }^{80}$ It was only when the Czech School Inspectorate was handed the responsibility for collecting disaggregated data that a more bullish approach was taken. Under this new approach, since adopted by the Ministry, all special and mainstream schools (with one or more Roma child in a special class) are obligated to record and

74 Ibid, Art. 2, \$2 (b).

75 D.H., 2006, para. $45,46$.

${ }^{76}$ D.H., 2007, para. 188, 189.

77 David Strupek, "Before and After the Ostrava Case: Lessons for Anti-Discrimination Law and Litigation in the Czech Republic", Roma Rights Journal 41, No. 1 (2008): 48, http:/ /www.errc.org /uploads/upload_en/file/03/66/m00000366.pdf.

78 Ondřej Klípa, "Chasing 'Statistical Roma': Ethnic Data Collection in Czech Primary Schools”, Journal on Ethnopolitics and Minority Issues in Europe 16, No. 1 (2017): 34-35.

79 Ibid.

${ }^{80}$ Zimová et al., "Strategic Litigation Impacts: Roma School Desegregation”, 37. 
send ethnic data to the Ministry. ${ }^{81}$ Although ethnic data collection from the government is not routinely forthcoming, ${ }^{82}$ it reveals the jurisprudential impact of $D . H$. , in that it has compelled the Czech government to engage in extra-legal activity to redress the disproportionate placement of Roma in special education. The fact that Czechia was unable to rebut the overwhelming statistical evidence presented in D.H. not only demonstrated a lack of a duty of care, but impressed on the Czech government that extra-legal measures were to be employed to effect the judgment.

As Goldston states, "data speaks for itself [and] it is an objective tool to monitor compliance with a judgment". ${ }^{83}$ Thus, the elevation of reliable statistical data also gives further credence to NGOs' calls for widespread reform and their roles as watchdogs monitoring implementation. For example, in a recent Rule Nine Submission to the Committee of Ministers (Council of Europe) in 2019, proposed changes to a 2016 Ministerial Decree aimed at facilitating aforementioned inclusion amendments to the 2004 Act raised serious concerns that the Czech education system is returning to a pre-D.H. state. ${ }^{84}$ The authors of the Submission especially pointed to the proposed diluting of the principle that SEN students are to be educated at mainstream primary schools and the possible establishment of SEN-only classes in separate schools ${ }^{85}$ - segregation in all but name. Figures show the number of Roma in reduced educational or SEN-specific programmes within mainstream primary schools increasing, whilst the total number of Roma in primary education has remained fairly static. ${ }^{86}$ With this data, NGOs are able to effectively rebut government claims that educational segregation is decreasing, exposing persistent and new threats to educational inclusion over a decade after D.H.

Despite the ECtHR elevating the position of reliable data in D.H., compelling the Czech government to take previously uncontemplated extra-legal measures and vindicating the role of NGOs, the organs of the state can still act to weaken or dilute an emancipatory judgment. In the 2013 Czech Supreme Court case of Jaroslav Suchý, concerning a Czech Roma man who had been sent to

\footnotetext{
${ }^{81}$ Klípa, “Chasing 'Statistical Roma'”, 35.

82 Albert, "Education policies in the Czech Republic", 184.

83 Interview with James Goldston, January 22, 2019.

${ }^{84}$ Amnesty International, Forum for Human Rights, Open Society Fund Prague, "Rule 9 Submission to the Committee of Ministers: D.H. and Others v. Czech Republic (Application No. 57325/00)", August 2, 2019, 2-5, https://search.coe.int/cm/Pages/result_details.aspx?ObjectId=090000168096 c5 5 2 .

85 Ibid.

${ }^{86}$ Ibid.
} 
a special school in his youth, the court found the data presented inadequate to prove his placement amounted to indirect racial discrimination. ${ }^{87}$ It was held that if statistical evidence was to establish a prima facie case of discrimination and shift the burden of proof, at least 50 percent of all Roma children would have to be shown to be in special education. At the time of Suchý's legal challenge, the Czech Ombudsman recorded that Roma represented 40 percent of all those in special education, absurdly meaning that the arbitrary threshold created by the court was not met. ${ }^{88}$ On appeal in 2015 , the Czech Constitutional Court also ruled against Suchý, upholding the judgment of the Supreme Court. It is clear that $D . H$. will not be a quick-fix, especially when the state fails to "[honour] the true spirit" 89 of a judgment, and extra-legal actors must continue to sustain pressure through data and other activism in order to ensure the promises of courtfought rights are not diluted and are eventually realised.

As illustrated when analysing both the specific response of the Czech government and its ministries and the elevation of reliable statistical data in European jurisprudence, it is evident that there must exist a strong partnership between legal and extra-legal actors and methods to fully realise educational equality. Changing legal and jurisprudential landscapes is no guarantee for tangible changes on the ground; however, a close relationship between strategic litigation and extra-legal activism and actors has been shown to at least apply pressure and scrutiny in the face of ineffective or unwilling implementation efforts.

\section{Roma Responses}

Beyond reshaping jurisprudential and legal landscapes, the very aim of strategic litigation should be to vindicate applicants' rights but, more profoundly, to also impact victimised communities. Analysing Roma responses, $D . H$. has evidently been utilised by Roma to claim their court-declared rights, increased human rights consciousness in Roma communities and culminated in initiatives to educate parents when making decisions about their children's schooling. Additionally, extra-legal activism crucially confronts pushback from

\footnotetext{
87 “Czech Supreme Court: No Redressfor 'Special SchoolEnrolment”, Romea.cz,January3, 2013, http:// www.romea.cz/en/news/czech/czech-supreme-court-no-redress-for-special-school-enrollment.

${ }^{88}$ European Roma Rights Centre, "Written Comments of the European Roma Rights Centre Concerning the Czech Republic: For Consideration by the Human Rights Committee at its 108th Session (8-26July 2013)", 10, http://www.errc.org/uploads/upload_en/file/czech-republic-iccpr-14-june -2013.pdf.

${ }^{89}$ Interview with James Goldston.
} 
victimised communities who, in response to slow implementation and decades of discrimination, may be cautious and fearful of exercising their court-declared rights.

When interviewing Goldston, one of the major impacts of D.H. discussed was the confidence given to the Roma community that the law, as interpreted by an influential supranational body, was "after decades of [...] being seen as something to fear [...] used to grant justice to a community that has been deprived of it for so long". ${ }^{90}$ Renewed faith in the law and its structures is of major significance because victims can utilise judgments to empower themselves and actively become part of implementation efforts. An apt example is the Ostrava schools campaign in 2014 which was led by Roma parents and supported by the Czech NGO Vzájemné soužití (Living Together). Kristýna Vaněrková, recalling an all too common story, prepared her grandson for a mainstream primary school entrance exam and organised mentoring through Vzájemné soužití but, when it came to finally enrolling her grandson to the school, she was told unequivocally that Roma belonged to the local practical school. ${ }^{11}$ With sustained pressure from Roma parents and local NGOs, schools began to back-pedal after justifications for their decisions were demanded. Before the campaign, 95 percent of Roma parents in Ostrava expected their children to attend practical schools; however, after the campaign, 20 percent of Roma parents expected to see the same result. ${ }^{92}$ Such a dramatic shift in Roma attitudes clearly illustrates the vital relationship between legal and extra-legal strategies, with $D$.H. being shown to be a weapon for Roma parents to wield in everyday situations.

Having conducted a field trip to Člověk v tísni in Kladno with Charles University in 2018, it was clear from speaking to a youth worker that Roma-led activism continues. Echoing accounts from the Ostrava campaign in 2014, the youth worker described a similar pattern: Roma parents enrol their child into a mainstream primary school, their application is rejected due to alleged oversubscription and they are told to send their child to the local practical school which is exclusively attended by Roma children. ${ }^{93}$ An important part of Člověk v tísni's function in Kladno is to work with affected parents to demand not only a justification for their child's application's being rejected, but evidence that a school

\footnotetext{
90 Ibid.

91 Ostalina-Maya Ovalle, "How Families are Taking Action against Czech Discrimination”, April 29, 2015, https://www.justiceinitiative.org/voices/how-roma-families-are-taking-action-against -czech-school-discrimination.

92 Ibid.

93 Sys, "The Hostel on the Hill".
} 
is at full capacity. The social worker wryly described that when inquiries are made, "suddenly a place at the [mainstream] primary school opens" ${ }^{94}$ What the extra-legal activism in Ostrava and Kladno demonstrates is that, whilst strategic litigation is a potent tool, extra-legal activism is needed to enforce previously denied rights at a local level.

In addition to reacting to incidents of discrimination, D.H. has been used, often with the aid of local NGOs, to disseminate information to the Czech Roma community. A paradigm shift in Roma human rights consciousness can be demonstrated through the work of the Czech NGO Slovo 21 which is mostly led by Roma and collaborates with Roma communities throughout Czechia. In 2013, Slovo 21 created the campaign "Mami, tati, já chci do školy" ("Mum, Dad, I Want to Go to School") which aims to educate Roma parents on the importance of mainstream schooling and the need to avoid practical schools unless absolutely necessary. ${ }^{95}$ Through music, videos, workshops, public meetings and home visits, NGOs like Slovo 21 work hard to ensure that the rights fought for in D.H. permeate into the Roma community. ${ }^{96}$ This is of immense importance because, instead of always being regarded as helpless, empowering and giving agency to Roma parents can transform everyday victims into everyday activists, having the potential to create widespread dissent against the status quo. ${ }^{97} \mathrm{With}-$ out post-judgment extra-legal efforts, within and including the Roma community, $D . H$. would be left in a vulnerable position because the fight for emancipation would cease in the courtroom.

Although the increasing human rights consciousness and mobilisation of the Roma community is encouraging, data collected since the D.H. judgment provides for "grim" reading and demonstrates that the impact of $D . H$. has not completely filtered down to the victim level..$^{98}$ Reviewing its progress from 2009 to 2013, the Czech government argued that the number of Roma children in

\footnotetext{
94 Ibid.

95 "Mami, tati, já chci do školy [Mum, Dad, I Want to Go to School]", official homepage of Slovo 21, 2014, https://www.slovo21.cz/index.php/extensions/vsechny-romske-projekty/310-mami-tati-ja -chci-do-skoly.

96 "Slovo 21: Praktická škola není pro budoucnost romských dětí prospěšná [Slovo 21 - A Practical School is Not Beneficial for a Roma Child's Future]", Romea.cz, November 19, 2013, http:// www.romea.cz/cz/zpravodajstvi/tiskove-zpravy/slovo-21-prakticka-skola-neni-pro-budoucnost -romskych-deti-prospesna.

97 Alphia Abdikeeva and Alina Covaci, "The Impact of Legal Advocacy Strategies to Advance Roma Health: The Case of Macedonia”, Health and Human Rights Journal 19, No. 2 (December 2017): 104.

98 Zimová et al., Strategic Litigation Impacts: Roma School Desegregation, 47.
} 
practical schools had significantly decreased year on year, with the trend set to continue. ${ }^{99}$ However, not concurring, the Czech School Inspectorate recorded in 2013 that 28 percent of all children diagnosed with "mild mental disabilities" were Roma, increasing to 32 percent in $2014,{ }^{100}$ and then decreasing marginally to 30.9 percent in 2017. ${ }^{101}$ Although numbers of Roma in practical schools have been somewhat affected by D.H., new challenges have emerged even at the level of integration. In 2018, the Czech Ombudsman exposed a "separate but equal" attitude at mainstream primary schools which, having accepted Roma pupils, were increasingly segregating them from non-Roma into separate classes and buildings. ${ }^{102}$ The hard facts show that the implementation of $D . H$ is painfully slow, segregation is taking new forms and, as reported by NGOs, victims may be facing new forms of educational inequality.

In addition to a lack of implementation, a worsening hostile environment in Czechia, characterised in part by an increase in public support for the radical populist party Svoboda a prrímá demokracie - Tomio Okamura (Freedom and Direct Democracy - Tomio Okamura) whose leader has openly denied the Roma Holocaust, ${ }^{103}$ is perhaps why there has been a pushback from sections of the Roma community. The OSJI recorded that, although D.H. unequivocally supported Roma educational equality, some Roma parents continue to consciously send their children to sub-standard practical schools. ${ }^{104}$ Messing makes the case that this type of pushback is due to a "safe island" mentality from the Roma community where, in order to "escape anti-Roma hatred" in mainstream primary schools, parents will take decisions on schooling based on the protection

99 Ibid.

${ }^{100}$ Amnesty International, Must Try Harder: Ethnic Discrimination of Romani Children in Czech Schools (London: Amnesty International Ltd., 2015), 6, https://www.amnestyusa.org/files /musttryharder_embargoed_report.pdf, accessed: March 18, 2019.

101 Štěpán Drahokoupil, "Discrimination against Roma in Education: Waiting for Changes on the Ground”, European Implementation Network, March 11, 2017, http://www.einnetwork.org /ein-voices-archives/2017/3/22/discrimination-against-roma-in-education-waiting-for-changes-on-the-ground-VkDd8.

102 "Doporučení veřejné ochránkyně práv ke společnému vzdělávání romských a neromských dětî" [Recommendations of the Ombudsman for the Joint Education of Roma and non-Roma Children] December 12, 2018, 31, https://ochrance.cz/fileadmin/user_upload/ESO/86-2017-DIS-VB _Doporuceni_desegregace.pdf.

103 Gwendolyn Albert, "Ignorance Breeds Contempt: Czech Holocaust Denial, the Pig Farm, and the Romani Genocide”, Heinrich Böll Stiftung Prague, December 19, 2017, https://cz.boell .org/en/2017/12/19/ignorance-breeds-contempt-czech-holocaust-denial-pig-farm-and-romani -genocide.

104 Zimová et al., Strategic Litigation Impacts: Roma School Desegregation, 58. 
of their children from majority population hostility. ${ }^{105}$ Amnesty International have corroborated this fear and concluded that, in Czechia, a widespread culture of racialized bullying exists in mainstream primary schools: "Every week I am reminded that I am Roma, that I am dirty and that I am different". ${ }^{106}$ As the attempted suicide of a Roma school girl in Česká Lípa in 2018 illustrates, racebased harassment at mainstream schools and a lack of action from head teachers continue to surface. ${ }^{107}$ It is little wonder, with accounts like these, that Roma may want to send their children to racially homogenous safe spaces where Roma language, culture, history and identity is not ridiculed or hidden away.

The fear-induced pushback is exactly why legal strategies are vulnerable and cannot be solely relied upon to effectively implement long-lasting societal change. As Cashman states, educational and wider social segregation was, before any court case, "uncritically accepted by Roma for generations" as part of their daily experience. ${ }^{108}$ The experience of the Roma community, from their attempted extermination during the Porajmos (the Holocaust), forced assimilation under Communism, ${ }^{109}$ unlawful sterilisation of Roma women ${ }^{110}$ and other forms of social persecution, cannot be undone by a legal declaration of rights. The wounds run deep and, although successful pieces of strategic litigation like D.H. can go some way in condemning historical wrongs, the use of extra-legal activism is vital in giving confidence to the Roma community and instilling a strong sense of personal identity to counter widespread discrimination.

The "safe island" mentality of the Roma community should also be discussed in the context of recent legislative reforms. The aforementioned amendments to the 2004 Act in 2015, and accompanying auxiliary Ministerial Decrees in 2016, attempted to establish a regime of inclusive education. This now includes the

105 Vera Messing, "Differentiation in the Making: Consequences of School Segregation of Roma in the Czech Republic, Hungary and Slovakia”, European Education 49, No. 1 (March 2017): 95, doi: $10.1080 / 10564934.2017 .1280336$.

106 "Segregation, Bullying and Fear: The Stunted Education of Romani Children in Europe", Amnesty International, April 8, 2015, https://www.amnesty.org/en/latest/news/2015/04/the-stunted -education-of-romani-children-in-europe/.

107 "Romani Girl Attempts Suicide after Bullying at her Primary School in Czech Town", Romea. $c z$, October 30, 2018, http://www.romea.cz/en/news/czech/romani-girl-attempts-suicide-after -bullying-at-her-primary-school-in-czech-town.

108 Cashman, "No Label No Progress", 597.

109 Filip Sys, "Why are Czech Roma in Ghettos?”, Fil Sys Blog, January 29, 2018, https://filsysblog .wordpress.com/2018/01/29/why-are-czech-roma-in-ghettos/.

110 Gwendolyn Albert and Marek Szilvasi, "Intersectional Discrimination of Roma Women Forcibly Sterilized in the Former Czechoslovakia and Czech Republic", Health and Human Rights Journal 19, No. 2 (December 2017): 28. 
safeguard that a child cannot be legally educated in a practical school without the informed consent of a parent or legal guardian. ${ }^{111}$ However, such developments do not adequately address historical abuses. For example, the Awen Amenca association helps to educate Roma parents on the importance of mainstream primary school enrolment for their children and encourage applications to previously "closed" school districts, assisting in legal action where necessary. ${ }^{112}$ On the other hand, it must also be accepted that while one avenue of discrimination is being tackled, new forms of discrimination in education - be that segregated classrooms or reassignment to different schools once teaching begins - are starting to pose new challenges to the ultimate aim of inclusive education in Czechia. ${ }^{113}$

Conversely, some accounts of why Roma make the decision to send their children to mainstream primary schools are disturbingly skewed: "[my father] wants us to belong to the white people [...] he never taught us cikánsky (Romani) $[\ldots .$.$] he does not see the value of being Roma in Czech society". { }^{114}$ This socially engineered inferiority complex was further uncovered during a Channel 4 News report on the Czech Municipal Elections in 2018. Speaking to a Roma community leader in the city of Most, O'Brien reported some Roma starting to believe they were actually "animals" because of the racist election posters surrounding the city, advocating for their forced ghettoization. ${ }^{115}$ To effectively redress the disastrous consequences of generational social exclusion, one must go beyond legal strategies and realise that members of marginalised communities may not instantly empower themselves with court-declared rights due to lived and historically-based experiences. Therefore, extra-legal activism must, following legal outcomes, seek to give agency to Roma communities and to include them in the implementation process in order to create effective and sustainable impact.

Positively, Roma have increasingly organised to counter the prevailing narrative of inferiority in Czech society through confronting blanket attacks by state actors and celebrating their culture and history. In the run-up to the Czech Presidential elections in 2018, a poignant example of Roma-led extra-legal activism

111 Zákon 82/2015 Sb., \16 and 19 (j); Vyhláška č. 27/2016 Sb., \4 (1).

112 "Magdalena Karvayová: Parents in the Ghettos Need to See Education Offers their Children a Future", Romea.cz, July 23, 2020, http://www.romea.cz/en/news/czech/magdalena-karvayova -parents-in-the-ghettos-need-to-see-education-offers-their-children-a-future.

113 Ibid.

114 Kazuyo Igarashi, "Support Programmes for Roma Children: Do They Help or Promote Exclusion?”, Intercultural Education 16, No. 5 (2005): 450, doi: 10.1080/14675980500378508.

115 Paraic O’Brien, "Far-Right in the Czech Republic: The Politicians Turning on the Roma”, News Report, 9:35, Channel4News, October5, 2018, https://www.channel4.com/news/far-right-in-czech -republic-the-politicians-turning-on-roma. 
was triggered by President Zeman calling Roma "work shy" and "inadaptable". 116 In response, the Roma community mobilised and started to post pictures of themselves at work in Czechia and abroad on social media. ${ }^{117}$ Supporting grassroots activism and giving agency to Roma communities to individually or collectively defend their educational and other civil rights, arguably, has a more instant social impact and goes some way to demonstrate that legal strategies should not solely be relied upon to organically effect change.

Furthermore, events like the annual Khamoro (World Romani) Festival118 and International Roma Day help to mould a strong sense of personal identity amongst Roma communities, whilst encouraging Roma led-action against persistent abuses in public life. ${ }^{119}$ For example, the 2019 International Roma Day in Brno included a collaborative sound installation by local Roma groups and the National Theatre which played stereotypical comments and racial insults about Roma to passers-by. ${ }^{120}$ Extra-legal activism can play a crucial role in giving agency to victimised communities and aiding implementation of judgments like $D . H$. at a local level. If that extra-legal activity can be spearheaded by Roma, the impact of D.H. and other future legal action could and would become more profound.

\section{Conclusion}

Václav Havel once said that the treatment of the Roma was a "litmus test" for society and that "efforts should be made to [...] drive out manifestations of intolerance". ${ }^{121}$ Through the lens of D.H. and Czech Roma educational desegregation efforts, this study has assessed the use and impact of strategic litigation - one

116 Celia Donart, "Opinion: Anti-Roma Stigma of Czech President Miloš Zeman Threatens Progress over Romani Rights”, University of Liverpool, January 24, 2018, https://www.liverpool.ac.uk /history/blog/2018/czech-president-roma/.

117 "Romové zaplavili Facebook stovkami fotografií, kde je vidět, jak pracují a vzkazují Zemanovi: pracujeme, přestaňte nás urážet! [Roma Flooded Facebook with Hundreds of Photos Showing How They Work and Tell Zeman: We Work, Stop Insulting Us!]”, Romea.cz, October 3, 2018, http://www.romea.cz/cz/zpravodajstvi/domaci/romove-zaplavili-facebook-stovkami -fotografii-kde-je-videt-jak-pracuji-a-vzkazuji-zemanovi-pracujeme-prestante-nas-urazet.

118 “Program Khamoro 2020”, Khamoro.cz, n.d., https://www.khamoro.cz/cs/program.

119 "International Roma Day: A Day to Raise Awareness of Human Rights Problems Experienced by Roma”, ERRC, April 6, 2007, http://www.errc.org/cikk.php?cikk=2740.

120 "International Roma Day - Events in the Czech Republic", Romea.cz, April 8, 2019, http://www .romea.cz/en/news/czech/international-romani-day-2019-events-in-the-czech-republic.

121 Henry Kamm, "Havel Calls the Gypsies a Litmus Test", The New York Times, December 10, 1993, https://www.nytimes.com/1993/12/10/world/havel-calls-the-gypsies-litmus-test.html. 
such method to "drive out" intolerance - in effecting social change. Grounding the discussion through a brief analysis of the attractive but obstacle-ridden pursuit of strategic litigation and then conducting a more specific legal and victim-impact analysis of D.H., this study has argued that strategic litigation cannot organically effect social reform and must be closely partnered with extra-legal activism in order to maximise impact. Regarding practical appeal, the potential of strategic litigation to bind respondent states to reforms, when no such activity was previously contemplated, is a draw for litigators and activists alike and demonstrates the impact of legal routes to redress. Although D.H. found an entire national education system to be structurally discriminatory and subsequently influenced further Roma educational desegregation litigation in Europe, court declarations cannot independently implement on-the-ground reforms.

Despite challenges to implementation, there exists a raw emotional aspect in representing and furthering a victimised community's rights in court. Whether through the law being shown to provide previously-denied justice to Roma communities or setting a precedent for lawyers, activists and victims on which to further build and rely, strategic litigation can have a generational impact. However, in order for that impact to be sustainable and for a positive narrative of emancipation to be constructed, extra-legal activism must be employed to ensure that the progress made in court is not diluted or disregarded by a respondent state. The extra-legal activism should also seek to holistically address the social consequences of educational segregation. The conclusion that strategic litigation is vulnerable and requires extra-legal support is further crystallised when considering historically hostile socio-political environments, choosing victim-centred strategies of redress and the risk of impotent court remedies.

Reviewing the impact of D.H. on legal landscapes, from Czech domestic developments and ECtHR jurisprudential perspectives, it is evident that extra-legal measures play a crucial role in the implementation of a judgement and the pressure applied to respondent states. Compliance with, and implementation of, the $D . H$. judgment by the Czech government has been consistently monitored with concern by extra-legal actors. It is this extra-legal monitoring and subsequent pressure which has arguably caused an escalation in scrutiny of Czech educational desegregation efforts - namely the EU Commission initiating infringement proceedings in 2014 - and influenced recent Czech legislative reforms.

Jurisprudentially, the post- $D . H$. impact of elevating the use of reliable data acted to not only vindicate the function of extra-legal actors, but to also compel the Czech state to take extra-legal measures itself (in the form of ethnic data 
collection) to redress the disproportionate placement of Roma in special education. Analysing changes to legal and jurisprudential landscapes post-D.H. strengthens the argument that a close relationship between strategic litigation and extra-legal activism can at least apply further pressure and scrutiny against ineffective or unwilling implementation efforts by governments.

It is perhaps when one reviews the impact of D.H. on the Roma community that both the vulnerability of strategic litigation and the need for extra-legal collaboration are most evidently displayed. The field trip to Kladno and past campaigns in Ostrava led by Roma parents and supporting NGOs have shown Roma themselves weaponising D.H. to enforce their court-declared rights at a local level. Increased human rights consciousness of the Roma community additionally can be seen as further evidence of legal and extra-legal activism working in tandem to effect change on a social level. However, one must appreciate that current statistical evidence of Roma in special education and reports of racialized bullying continue to describe a dire situation. There is much work to be done and, as one reflects on generations of Roma social segregation, giving agency to Roma communities to claim their court-declared rights will be a gradual, sensitive but vital process moving forward. 